root hairs hold the soil physically and prevent its erosion into streams, rivers and reservoirs. In the spring, forests provide the shade which prevents over-rapid melting of snow. This limits flooding and reduces spring run-off.

Forest lands provide habitat for most big game species and some game birds. Recreational use of Saiskatchewan's forests is increasing yearly and forests must be managed to maintain a continuing fish and game population for the growing numbers of hunters and anglers. In addition, forest areas containing lakes and streams, attract campers, picnickers and others who simply wish to enjoy, study or photograph the scenic beauty, animals and plants that are found there. Swimming, water-skiing, and boating are enjoyed in bodies of water bordered by forest land.

The forest provides food and shelter for most fur bearers, upon which many trappers in Saskatchewan's wooded areas depend for a livelihood. The beaver is considered of valuable assistance in forest conservation. Beaver dams help control water levels, prevent erosion and may eventually lead to the formation of rich glades in the forest, known as beaver meadows.

Cattle grazing is permitted in Saskatchewan's provincial parks and in some parts of the provincial forest. Grazing must be prohibited in recreational areas. Excessive grazing in forests reduces forest reproduction and competes with the food needs of wildlife.

Perhaps the most important conservation measure that we can apply in any forest area is fire prevention. Each year, thousands of acres of valuable timber land are destroyed by fire and about 85 per cent of these fires are caused by human carelessness. F o r e s t conservation should therefore not be restricted to Forest Conservation Week. As custodians of our forest heritage, it is our responsibility to take every precaution against fire, all year round, when camping, fishing, hunting or travelling in a wooded area. One tree will make a million matchesdon't let one match destroy a million trees!

\section{A NATURAL APPROACH TO NATURE}

By H. Kagis, Department of Nalur Resources

Even animals seem to indulge classification: they eat certain thin and reject others. Consequently the are two "classes" of things for the - eatables and non-eatables. Human who are so proud of their science often use classifications the ma features of which recall the "classif cation" just mentioned: first, pure. utilitarian criteria are used; secon a single distinguishing feature is ar plied.

The simpler such classification are the easier it is to express the in popular doctrines and even slc gans. Such doctrinized classificatior can hamper the development of th human mind by offering ready-mad explanations and blocking scientif examination. We have to rememibr that in principle no classificatid should be anything more than a to for understanding. We have to $r$ member, furthermore, that any pa: of nature is related to its surrounc ings, or, to use the scientific term, an open system.

Such an approach to nature in $g \epsilon$ neral and to living nature in part cular is gaining more and mol ground. Science has gone from study ing single plants and animals studying them as societies and h: finally arrived at attempts to undei stand whole areas as natural unit comprising soil and plant life an animal life, including microscop: organisms. A very important featur of such an approach is that thes units are not viewed as unchangin and that an attempt is made to se the changes that occur as eac constituent element influences th others. Many scientific names ar used for such units, as ecosystem: biochores, biogeocenoses, etc.; eac of these terms has a somewhat dif ferent meaning, but they all tend $t$ embrace a natural unit in its entity a concept fundamental to such a clas sification.

During the little walk at Emm Lake, an attempt was made to dis tinguish some such natural units and to see the functions and inter relations of their constituent ele ments. The first of such units wa 
the lakeshore. There the vegetation (Scirpus, Juncus, Calamus, etc.) by growing, dying off, and settling to the bottom, modifies those growing conditions which favoured its initial appearance. A classification that would stop at calling such a lakeshore, for instance, a hydrophytic plant society would probably satisfy some plant sociologists, but it would convey a static picture. It would probably be better to use the everyday name of lakeshore, because this name would not restrict the picture to a single element, the plants.

Such an attempt to comprehend natural units in their entity might seem the most normal thing in the world. But there have been scores of attempts made to explain all processes that take place in a locality and characterize them by just one element. This seems to be the result of specialization in science. It cannot be denied that one element, for instance water or soil, initially plays a prominent part in creating such natural units, but later a major formative role can be played by the vegetation, by animals and also by man.

Thus the next place observed, a mixed-wood stand of trembling aspen and white spruce, again showed the interaction of different elements. The stand was not very dense and various plants, including patches of moss, covered the ground. There were scattered sarsaparilla (Aralia nudicaulis), three species of wintergreen (Pyrola spp.), bedstraw ( $G a-$ lium boreale), twin flower (Linnaea borealis), bishop's c a p (Mitella $n u d a)$ and others, indicating a cool, moist site. The humus and soil in turn showed the influence of this plant society (including the trees as a major factor). A different plant society, for instance a grass cover, would have had a different influence. The plant cover modifies the amount of light penetration, the temperature above and below the ground (at Doré Lake, under a stand of balsam, frozen ground was encountered at the depth of 38 inches on July 24), and bacteria, fungi and chemical processes.

At the outing it was found that in an open stand of black spruce in a muskeg the humus was fiozen at a depth of six inches, showing that the moss and the upper layer of peat had a very decisive influence on the life processes there. The penple call it muskeg; they do not calll it a moss area or a tract of black spruce. This means that the common man is sometimes wiser than the scientists; he apparently wants to convey the idea that this is a place where there is a certain moisture regime, a certain plant society, which varies with the degree of moisture, the tree growth, etc.

All this might seem so much theory or pure science. But some bitter experience has shown that actions influenced exclusively by momentary practical considerations have led to very undesirable results, especially in fcrestry. Considerable losses have been sustained by creating favourable conditions for the spreading cf insects and diseases. Large areas have also been made simply unproductive. Therefore, considerable attention has been paid lately to the studies of natural units including soil, vegetation animal life, microflora and microfauna and to the interaction of all these elements.

\section{Reports from Audubon Junior Clubs}

In this issue of the Blue Jay we want to give recognition to the active study and conservation programmes being carried on by young people in the Prairie Provinces through the Audubon Junior Clubs. We should like to think that all these boys and girls are readers of the Blue $\mathbf{J a y}$, and we invite contributions from them either as individual submissions to the Boys' and Girls' Section or as group reports on their club activities.

Here are some typical reports of Audubon Junior Club activities. Reporting for the club at Springside, Sask., the leader, Mrs. M. Barber, tells of field trips around the school and out to the creek nearby. The group goes out in fall, for example, to watch for signs of approaching winter. Indoors, the members have 